ARTICLE HISTORY: Received: August 19, 2021 Accepted: October 12, 2021 Published: October 19, 2021

ФИЛОСОФИЯ «ДАО» КАК ОСОБЫЙ ПУТЬ В ВОСПИТАНИИ ЛИЧНОСТИ

\author{
Саидова Камола Усканбаевна \\ Самостоятельный соискатель Национального \\ Университета Узбекистана имени Мирзо Улугбека \\ Республика Узбекистан, г.Ташкент, 100095, ул.Университет, д.4
}

\title{
THE PHILOSOPHY OF "TAO" AS A SPECIAL WAY IN THE EDUCATION OF PERSON
}

\author{
Kamola U. Saidova \\ DSc Candidate of the National University \\ of Uzbekistan named after Mirzo Ulugbek \\ Republic of Uzbekistan, Tashkent
}

\begin{abstract}
Аннотация. Статья посвящена философии «Дао», одного из древних китайских учений, нацеленного на совершенствование воспитания личности. Автором показывается, что даосское учение являет собой сложную систему единения мира и человека, где особое внимание уделяется семейным отношениям. Важным критерием является то, что благодаря благому воспитанию, представляющего собой истинный путь жизненного Дао, можно достичь состояния истинной гармонии и душевного порядка.

Abstract. The article is devoted to the philosophy of "Tao", one of the ancient Chinese teachings, aimed at improving the education of the individual. The author shows that Taoist teaching is a complex system of unity between the world and man, where special attention is paid to family relations. An important criterion is that thanks to good upbringing, which is the true path of the Tao of life, one can achieve a state of true harmony and mental order.

Ключевые слова: Дао, философия, путь, воспитание, семья, человек, общество, совершенствование, счастье, гармония.
\end{abstract}

Key words: Tao, philosophy, path, education, family, person, society, perfection, happiness, harmony.

Китайская философия в своём развитии устанавливала определённые отношения в семье между людьми в вопросах воспитания личности, порой учитывая особое соблюдение пути «Дао». Однако «хотя слово «Дао» обычно переводят как путь, для последователей даосизма этот термин имел более глубокое значение. Для них «Дао» - начало всех вещей, великий единый комплекс небытия, из которого появилось бытие, и, следовательно, все существа и вещи. Само по себе «Дао» не сущность, а всеобщее и безымянное, через которое появились все именованные вещи, унаследовав от «Дао» то, что называется «Дэ» энергию или силу и то, чем вещь является по своей природе. «Дао» производит квинтэссенцию, «Дэ» наделяет её природой. Человек должен всегда следовать «Дэ», ограничивая свои действия только тем, что необходимо или естественно для него никогда не прилагая чрезмерных усилий, сделав простоту своим руководящим принципом, а удовлетворённость целью» [8, с. 120], тем самым, самовоспитывая в себе умеренность и благонравие.

Изначально важно отметить, что «нарушение требований дао ведёт к «затемнению» природы человека, проявлению злых наклонностей и действий. Даосисты не отрицали значение совершенствования природы человека, признавали влияние окружающей среды на человека и его природу, но главную свою задачу они видели в том, чтобы отрешиться от влияния окружающего общества, которое они считали пагубным и неисправимым. Особый упор на это делал Чжуан-цзы. Он полагал, что человек возник «вследствие изменений». В годы, отведённые ему природой, человек подвержен переменам, как всё сущее, однако перемены эти происходят так быстро, что нет возможности противостоять им. Чжуан-цзы считал, что природа человека и окружающий мир вследствие своей бесконечной и скоротечной изменчивости непознаваемы. Природа человека - в естественности, жизнь - в недеянии» [5, с. 53], что и предопределяло, по мнению даосов, спокойную и размеренную жизнь всего общества.

И, как мы можем понимать, философия даосизма провозглашает именно то, что «целовек не уничтожается, следующий дао: скорее, он, напротив, «усиливается», достигая состояния совершенства и высочайшей уместности каждого из своих поступков» [4, с. 151], что и определяло правила поведения людей, как в обществе, так и в семье.

Культурный и политический деятель Китая III века - Люй Бувэй, будучи сторонником даосизма, с философской точки зрения одобрял разумное воспитание и самосовершенствование, ведь «основа государства в человеке. Существуешь сам, существует и семья; существует семья, существует и государство; существует государство, существует и Поднебесная. Поэтому говорят: “Человек - основа семьи, семья - основа государства, государство - основа Поднебесной»» [3, с. 596]. При всём этом, «если правитель прост, как дао, 
то он защищён ближними. Самое высшее для него - это требовать с себя, а уж затем спрашивать с других. Он отдаляет от себя людей недалёких, отстраняет тех, кто стремится к силе» [3, с. 596]. Иными словами, всё это способствует помогать сохранению стабильности и благим отношениям между государством и обществом.

Один из видных представителей даосизма, Гэ Хун (283-343 гг.), в своём труде «Баопу-цзы» обращает наше внимание на возмездие, а именно: «Когда человек покушается на чужое имущество, результаты совершения этого злодеяния могут отразиться на членах его семьи, жене и детях и привести к их смерти, хотя и не сразу после совершения преступления. Если размер злодеяния не таков, чтобы погубить домашних совершившего его человека, то на его семью обрушиваются такие беды, как наводнения, пожары, грабежи и кражи... Поэтому даосы говорят, что убивиий невинного человека сам будет сражён насмерть оружием, а отнявший у других имущество ради собственного обогащения не сможет избежсать возмездия» [2, с. 262-263]. И, собственно, «Гэ Хун сделал следующий шаг в разработке представлений о воздаянии, указав на связь между здоровьем и долголетием, с одной стороны, и нравственным поведением - с другой. Добрые поступки истощают болезнетворных чудовищ, обитающих в теле, а прегрешения, напротив, способствуют их росту. Таким образом, мысли и действия индивида влияют на его здоровье и долголетие» [2, с. 263]. Следовательно, путь «Дао» проявляется через процесс воспитания личности и воплощается в ежедневных поступках людей.

Л.Ф.Федотова утверждает о том, что «основой всего, всех отношений в обществе, тем корнем, с установлением которого «рождается путь», является «сыновняя почтительность» (сяо) и «уважение к стариим» (ди). Тот, кто обладает этими качествами «от природы», не нуждается в «учении». Во всех слоях общества культивировалась сыновняя почтительность и уважение старших» [12, с. 83]. При всём этом, «если учесть, что основу китайского общества составляли большие семьи, общины, объединявшие несколько поколений, старших и младших, при этом деревня, фактически, тоже напоминала большую семью, то становится ясным, какую цементирующую роль играл здесь принцип сыновней почтительности» [12, с. 84]. Следовательно, согласно философии «Дао», единство человека со своей семьёй - позволяет людям познать безмятежность и счастье в жизни.

И, как мы можем понимать, ценность семейных отношений в философии даосизма занимает особое место. Однако «счастье для даоса заключено в познании смысла перемен и обретении неизменного состояния dyxa. Это противоречило многим конфуцианским установкам общества, где счастье понималось как многодетность в семье, почитание предков, соблюдение иерархической субординации в обществе, где «всё находится на своих местах»»» [11, с. 455]. При всём этом, по заверению А.Е.Лукьянова, «новая теория Дао запускалась Конфуцием в организм семейных отношений от каждой малой семьи до единой семьи Поднебесной и подготавливалась к восприятию людьми как исконный закон жизни первопредков» [10, с. 104], что позволяет оптимизировать нормы поведения, чтобы всё остальное пришло в равновесие.

Мэн-цзы, будучи представителем конфуцианства, но, тем не менее, придерживаясь философии «Дао», описывая «Путь благородного» в плане семейного воспитания, задаётся вопросами и сам же на них отвечает: «Спрашивают: что значит быть отцом? Отвечаю: это значит быть щедрым и великодушным и придерживаться правил ли. Спрашивают: что значит быть сыном? Отвечаю: это значит выказывать почтение и любовь и соблюдать благопристойность. Спрашивают: что значит быть старшим братом? Отвечаю: это значит любить младших и навещать друзей. Спрашивают: что значит быть младшим братом? Отвечаю: это значит оказывать почтение старшим, слушаться их и не поступать неправильно. Спрашивают: что значит быть мужем? Отвечаю: это значит быть усердным и не предаваться безделию, самому наблюдать за всем в семье и соблюдать в ней различия. Спрашивают: что значит быть женой? Отвечаю: это значит быть покорной, послушной, внимательной и расчетливой, если муж соблюдает правила ли. Если же муж не соблюдает правил ли, то жена должна пребывать в страхе и побуждать к добродетели. Таково дао, и, если его не придерживаться, возникают беспорядки; если же его придерживаться всегда и во всём, беспорядкам приходит конец» [1, с. 233]. Таким образом, семейная сила «Дао» способна управлять миром, являясь источником всего того, что есть в нашей Вселенной.

Философия «Дао» прочно соединяет семейные отношения, где во главу угла превозносится истинная доброта. При этом «под изначальной добротой Мэн-цзы понимал главным образом четыре прирождённых специфических качества человека, исток которых - непосредственное спонтанное чувство, а завершение сознательное поведение: «Все люди обладают не выносящим чужого страдания сердцем... У всякого человека, вдруг увидевшего ребёнка, готового упасть в колодец, будет испуганное и страшащееся, соболезнующее и сострадающее сердце. И это происходит не из-за внутренней близости с родителями ребёнка, не из желания иметь хорошую репутацию среди соседей и друзей и не из отвращения к тому, что ребёнок разразится воплями. Отсюда видно, что не имеющий соболезнующего и сострадающего сердца не человек, не имеющий стыдящегося за себя и негодующего на другого сердца не человек, не имеющий отказывающего себе и уступающего другому сердца не человек, не имеющий утверждающего и отрицающего сердца не человек. Соболезнующее и сострадающее сердце - начало гуманности, стыдящееся за себя и негодующее на другого сердце - начало должной справедливости, отказывающее себе и уступающее другому сердце — начало благопристойности, утверждающее и отрицающее сердце - начало разумности. Человеку принадлежат эти 
четыре начала (сы дуань), так же как ему принадлежат четыре конечности (сы ти)» [7, с. 252]. Таким образом, наше сердце должно быть предельно чувствительным ко всем людям.

По мнению даосского философа Хун Цзычена (XVII в.), «в каждой семье есть своя истина. В сутолоке каждого дня есть истинный Путь. Когда люди могут, не кривя душой, жить в согласии и с радостью говорить друг другу приветливые слова, когда родители и дети любят друг друга и живут душа в душу, - это в тысячу раз выше «регулирования дыхания» и «созерцания сердца»» [6, с. 114]. Следовательно, важно совершенствовать «Дао» внутри самого себя, в своей душе, чтобы семейные отношения были в постоянной гармонии.

В конечном итоге мы должны помнить слова Лао-цзы о том, что «кто совериенствует дао внутри себя, у того добродетель становится искренней. Кто совершенствует дао в семье, у того добродетель становится обильной. Кто совершенствует дао в деревне, у того добродетель становится обширной. Кто совершенствует дао в царстве, у того добродетель становится богатой. Кто совершенствует дао в поднебесной, у того добродетель становится великой» [6, с. 28]. И, как мы видим, слова Лао-цзы о том «что тот, кто совершенствует «Дао» в семье, тот достигает изобилия» [9, с. 251], говорят о том, что именно философия «Дао» является законом и правилом жизни в процессе семейного воспитания личности. Именно «Дао» способно пронизывать собой сущее, оживлять и направлять всё то, в чём смысл бытия. И поэтому для каждого человека, жизнь становится подлинной, исполненной благости и совершенства, с воздержанием от низменных желаний во имя следования вселенского добра. В процессе своего взросления, человек, следующий истинному пути «Дао», забывает про корысть и тщеславие, становясь самим собой, и именно тогда жизнь начинает обретать особую гармонию и душевный порядок.

1. Антология мировой философии в 4-х томах. / Том 1. Философия древности и средневековья. Часть 1. - М.: Мысль, 1969. - 361 с.

2. Вонг Е. Даосизм. - М.: ФАИР-ПРЕСС, 2001. - 352 с.

3. Го Мо-жо. Философы Древнего Китая. (Десять критических статей / Перевод с китайского. - М.: Изд-во иностр. лит-ры, 1961. - 738 с.

4. Дао и телос в смысловом измерении культур восточного и западного типа: Монография / С.Е. Ячин и др. - Владивосток: Изд-во Дальневост. федерал. ун-та, 2011. - 324 с.

5. Древнекитайская философия. Собрание текстов в двух томах. Том 1. - М.: Мысль, 1972. - 363 с.

6. Душа Востока. / Хорев В.Н. - Ростов н/Д., 2011. - 348 с.

7. Кобзев А.И. Философия китайского неоконфуцианства. - М.: Вост. лит., 2002. — 606 с.

8. Крюгер Р. Китай. История страны / пер. Д.Воронина, Ю.Гольдберra; предисл. К.Королева. - СПб.: Мидгард, 2008. - 544 с.

9. Лао-цзы. Обрести себя в Дао / Сост., авт. предисл., перевод, коммент. И.И. Семененко. - М.: Республика, 1999. - 445 с.

10. Лукьянов А.Е. Начало древнекитайской философии («И цзин», «Дао дэ цзин», «Лунь юй»). - М.: Радикс, 1994. -112 c.

11. Мистерия Дао. Мир «Дао дэ цзина» / Сост., перев., иссл. и примеч. А.А.Маслова. - М.: Издательство «Сфера» Российского Теософского Общества, 1996. - 512 с.

12. Федотова Л.Ф. Философия Древнего Востока. - М.: Издательство «Спутник +», 2015. - 142 с.

\section{References}

1. The Anthology of World Philosophy in 4 volumes. / Volume 1. Philosophy of Antiquity and the Middle Ages. Part 1. - M.: Mysl, 1969. - 361 p.

2. Vong E. Taoism. - M.: FAIR-PRESS, 2001. - 352 p.

3. Go Mo-chjo. Philosophers of Ancient China. (Ten critical articles / Translated from Chinese. - M.: Izd-vo inostr. lit-ry, 1961. $-738 \mathrm{p}$.

4. Tao and telos in the semantic dimension of Eastern and Western cultures: Monograph / S.E.Yachin and others Vladivostok: Izd-vo Dalnevost. Federal. un-ta, 2011. - 324 p.

5. Ancient Chinese philosophy. A collection of texts in two volumes. Volume 1. - M.: Mysl, 1972. - 363 p.

6. The soul of the East. / Horev V.N. - Rostov on Don, 2011. - 348 p.

7. Kobzev A.I. Philosophy of Chinese Neo-Confucianism. - M.: Vost. lit., 2002. - 606 p.

8. Kruger R. China. The History of the Country / Trans. by D.Voronin, Y.Goldberg; preface by K.Korolev.- Saint Petersburgh: Midgard, 2008. - 544 p.

9. Laozi. To Find Oneself in the Tao / Comp., author's preface, translation, comment. I.I. Semenenko. - M.: Respublika, 1999. - 445 p.

10. Lukyanov A.E. The Beginning of Ancient Chinese Philosophy («I Ching», «Tao Te Ching», «Analects»). - M.: Radiks, 1994. - 112 p.

11. The Mystery of Tao. The World of «Tao Te Ching». / Comp., transl., issl. and note by A.A.Maslov. - M.: Izdatelstvo «Sfera» Rossiyskogo Teosofskogo Obshestva, 1996. - 512 p. 
12. Fedotova L.F. The Philosophy of Ancient World. - M.: Izdatelstvo «Sputnik+», 2015. - 142 p. 